\title{
Mast cell concentration and skin wound contraction in rats treated with Brazilian pepper essential oil (Schinus terebinthifolius Raddi) ${ }^{1}$
}

DOI: http://dx.doi.org/10.1590/S0102-865020150040000008

Lígia Reis Moura EstevãoI, Juliana Pinto de MedeirosiI, Ricardo Santos Simões ${ }^{\mathrm{III}}$, Rosa Maria Esteves Arantes ${ }^{\mathrm{IV}}$, Milene Alvarenga Rachid ${ }^{\mathrm{IV}}$, Regildo Márcio Gonçalves da Silvav, Fábio de Souza Mendonça ${ }^{\mathrm{VI}}$, Joaquim Evêncio-Neto ${ }^{\mathrm{VII}}$

${ }^{\mathrm{I}}$ Fellow PhD degree, Postgraduate Program in Animal Bioscience, Department of Morphology and Animal Physiology, Federal Rural University of Pernambuco (UFRPE), Recife-PE, Brazil. Surgical procedures, acquisition of data.

IIPhD, Associate Professor, Histology Division, Department of Morphology and Physiology, UFRPE, Recife-PE, Brazil. Conception and design of the study, critical revision.

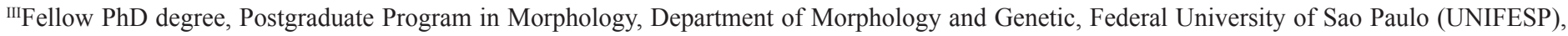
Brazil. Interpretation of data, manuscript writing.

${ }^{\text {IV }} \mathrm{PhD}$, Associate Professor, Histology Division, Department of General Pathology, Institute for Biological Sciences, Federal University of Minas Gerais (UFMG), Brazil. Acquisiton and interpretation of data.

${ }^{\mathrm{v}} \mathrm{PhD}$, Assistant Professor, Faculty of Sciences and Letters, UNESP, Assis-SP, Brazil. Acquisiton of data, obtaining the oil used.

${ }^{v} \mathrm{PhD}$, Associate Professor, Histology Division, Department of Morphology, UFRPE, Recife-PE, Brazil. Histopathological examinations, interpretation of data.

${ }^{\mathrm{VII}} \mathrm{PhD}$, Associate Professor, Histology Division, Department of Morphology, UFRPE, Recife-PE, Brazil. Scientific and intellectual content of the study, interpretation of data, critical revision.

\section{ABSTRACT}

PURPOSE: To evaluate wound contraction and the concentration of mast cells in skin wounds treated with 5\% BPT essential oil-based ointment in rats.

METHODS: Twenty rats, male, of adult age, were submitted to skin surgery on the right (RA) and left antimeres (LA) of the thoracic region. They were divided into two groups: control (RA - wounds receiving daily topical application of vaseline and lanolin) and treated (LA - wounds treated daily with the topical ointment). The skin region with wounds were collected at days 4, 7, 14 and 21 after surgery. Those were fixed in 10\% formaldehyde and later processed for paraffin embedding. Sections were obtained and stained by H.E for histopathology analysis. The degree of epithelial contraction was measured and mast cell concentration were also evaluated.

RESULTS: The treated group showed higher mast cell concentrations $(p<0.05)$ associated with increased contraction at day 7 and 14 respectively.

CONCLUSION: Ointment containing 5\% Brazilian pepper tree oil increases mast cell concentration and promotes skin wound contraction in rats.

Key words: Wound Healing. Phytotherapy. Mast Cells. Skin. Rats. 


\section{Introduction}

Tissue damage of any nature immediately activates events that promote wound healing. Fundamentally, the healing process occurs in three phases: inflammation, granulation, tissue formation and extracellular matrix deposition, and remodelling ${ }^{1}$.

Inflammation plays an essential role in the healing process. Immediately after the injury, begins platelet aggregation, haemostasis, and a complex interaction of inflammatory cells and chemical mediators begin to restore tissue ${ }^{2}$. When the wound enters the fibroblastic phase, the processes of extracellular matrix deposition, angiogenesis and reepithelialisation of the wound begin, which promote neoangiogenesis, collagen production by fibroblasts and cell migration. Complete repair of the tissues results from successive alternations of anabolic and catabolic reactions, including leukocyte participation in the primary production of proteases and growth factors ${ }^{1}$. In the final phase of healing, the collagen deposition is accentuated and most cells disappear. Resolution of the wound is considered complete only after total maturation and remodelling of the extracellular matrix ${ }^{1}$. In this phase, mast cells are essential to the healing process. They are predominantly found in the dermis, near the vascular tissue and the basement membrane of endothelial cells and nerves ${ }^{3}$. These cells present cytoplasmic granules that contain histamine, serotonin, tryptase and several cytokines (tumour necrosis factor, interleukin-4, fibroblast growth factors and epithelial cells), which are capable of stimulating the proliferation of endothelial and epithelial cells and fibroblasts ${ }^{3}$. When the inflammatory phase begins, these cells release several vasoactive mediators, which cause an increase in vascular permeability and oedema ${ }^{4}$. Mast cells are capable of inducing and exacerbating the angiogenesis process by releasing tumoural necrosis factor, tryptase and heparin ${ }^{5}$. Moreover, they accumulate at the wound's edge and participate in collagen remodellation ${ }^{6}$.

Medicinal plants have been used to improve the skin healing process ${ }^{7}$. Notwithstanding the fact that Brazil, the largest country in South America, is a land of diversified flora, research on natural drug development in Brazil is rare, as reported by Desmarchelier ${ }^{8}$. The Brazilian pepper tree (Schinus terebinthifolius Raddi) (BPT) is native to the Northeast, Central-West, Southeast and South regions of Brazil. In popular medicine, it has been used as a treatment for respiratory infections and digestive disorders, such as gastritis, gastric atony and diarrhea. Extracts from BPT have antimicrobial $^{9,10}$, antifungal ${ }^{11}$, antiparasitic ${ }^{12}$ and antiinflammatory healing properties ${ }^{13,14}$ and aren't toxic to humans ${ }^{15}$. Branco Neto et al. ${ }^{16}$ refers that the topic use of the hydroalcoholic extract of aroeira delayed the reepitelization of the skin wounds in rats. However Estevão et al. ${ }^{17}$ and Lipinski et al ${ }^{18}$ show the aroeira oil had a beneficial effect on wound healing by second intention.

The role of mast cells in healing has been widely discussed in the scientific community in recent years ${ }^{3,4}$. Different scientific studies have confirmed the efficacy of these cells at all stages of healing ${ }^{2}$.

\section{Methods}

The study protocol was approved by the Animal Ethics Committee of the Federal Rural University of Pernambuco (UFRPE) (process no $23082.014123 / 2011$ ).

Twenty adult male rats (Rattus norvegicus albinus), weighing $250 \mathrm{~g}$, with three months of age were obtained from the Morphology and Physiology Department of Federal Rural University of Pernambuco (UFRPE) animal colony.

The animals were housed in individual cages with commercial chow (Presence ${ }^{\circledR}$, Purina) and water ad libitum, maintained at $23-25^{\circ} \mathrm{C}$, under 12 hour light/dark cycle, in the animal colony at the Pharmacy Department of Rural Federal University of Pernambuco (UFRPE).

\section{Preparation of the extract of Schinus terebinthifo- lius Raddi}

Leaves of the pepper tree (Schinus terebinthifolius Raddi, Anacardiaceae) were collected in the morning of September 2010 on the campus of Federal Rural University of Pernambuco (UFRPE). The plant was identified by comparison with a previously identified specimen and deposited in the Herbarium Vasconcelos Sobrinho UFRPE under the number 49259.

To obtain the essential oil, fresh leaves (200g) were crushed and subjected to hydrodistillation technique in a modified Clevenger apparatus. After two hours of hydrodistillation the oil obtained was separated from water by density difference and excess moisture was removed with anhydrous sodium sulfate $\left(\mathrm{Na}_{2} \mathrm{SO}_{4}\right)$. The total oil amount was calculated based on the weight of fresh leaves. The oil was stored in amber glass container, tightly closed, kept in freezer, until the experiment, at a temperature of $-20^{\circ} \mathrm{C}$. The leaves oil study had its chemical profile reported by Silva et al. ${ }^{19}$, which identified thirty-three components, representing $95.5 \%$ of the oil. Among the majority of this oil compounds are p-Cymen7-ol (22.5\%), 9-epi-(E)-cariophyllene (10.1\%), carvone $(7.5 \%)$ and verbenone $(7.4 \%)$. 
With the oil, an ointment was manipulated with a lanolinvaselina formulation: lanolin anhydrous - 30\%; essential oil of aroeira leaf - 5\% VIT; e-oily acetate $-0.5 \%$; solid vaseline qsp $100 \mathrm{~g}$.

For the formulation of the ointment base, anhydrous lanolin (30\%), solid Vaseline (70\%) and vitamin E (0.5\%) was used $^{20}$. The ointment base was added to the essential oil at a concentration of $5 \%$ for use in each treatment group.

After a week of adaptation to the new environment, animals were anesthetized with a combination of xylazine $(20 \mathrm{mg} /$ $\mathrm{Kg})$ and ketamine $(100 \mathrm{mg} / \mathrm{Kg})$, administered intramuscularly ${ }^{2}$. The animals furry at thoracic region were shaved and antisepsis was performed with topical alcoholic chlorhexidine $0.5 \%$. The area was initially marked with the aid of $1.3 \mathrm{~cm}$ diameter cylinder. With a surgical blade and blunt scissors, incisions were made in skin and subcutaneous tissue on the right and left sides of the thoracic region, separated by a $2 \mathrm{~cm}$ distance. The tissue was dissected and removed leaving adjacent fascia exposed.

Immediately after surgical excision the wounds located on the right antimere, received a daily topical applications of the ointment lanolin and Vaseline base (vehicle) - control group (GCtrl) and the located on the left antimere, received a daily topical application of the ointment containing aroeira Leaf oil at $5 \%$ treated group (GTreat). The rats were then divided into four groups of five animals each according to the time of application of the ointment: 4th - 4 days of application; 7th - 7 days of application; 14th -14 days of application and 21th -21 days of application. Euthanasia was performed by increasing the anesthesia.

\section{Morphology and morphometry}

On 4th, 7th, 14th and 21th days after surgery, the wounds of each group were measured with the aid of a caliper graph (King Tools). The calculation of the average degree of contraction (C) was expressed as percentuals, being $\mathrm{C}=[(\mathrm{A} 0-\mathrm{Ai}) / \mathrm{Ao}] .100$, where $\mathrm{A} 0$ is the initial area of $\mathrm{mm}$ the wound (day 0) and Ai is the area of the wound in the 4th, 7th, 14th and 21 st days postoperatively. On day 0 (day of surgery) and 4th, 7th, 14th and 21st days after surgery, all wounds from each group were evaluated and measured with a calliper rule. For wound area calculation, the largest and the smallest diameters were observed. From these data, the wound area was obtained using the mathematical equation: $A=\pi$.R.r, in which A represents the area; $R$, the largest radius; and $r$, the smallest radius of the wound. The contraction degree calculation was expressed in percentages using the mathematical equation: $100 \times($ Wo $-\mathrm{Wi}) \div$ Wo, in which Wo is the initial wound area (day 0) and Wi is the wound area on the 4th, 7th, 14th and 21 st post-operative day.
After macroscopic analysis of the respective groups, the animals were anesthetized with isoflurane and a fragment was collected for histological analysis from each group (4th, 7th, 14th and 21 th postoperative days), the wound was dissected with a 0.5 $\mathrm{cm}$ margin of healthy skin around the lesion.

\section{Histological analysis}

After $24 \mathrm{~h}$ in $10 \%$ formaldehyde, tissue samples were dehydrated in increasing concentrations of ethyl alcohol and diaphanized in xylene. Samples were then processed for paraffin inclusion. For each animal cuts were made in the middle region of the flap sections longitudinal samples $(5 \mu \mathrm{m})$ were obtained parallel to the greater axis of fragments and stained with hematoxylineosin (H.E) for morphological and histometric analysis.

To quantify the number of mast cells in each wound, six images were obtained and analysed by Image Pro-plus ${ }^{\circledR}$ software. The parameters obtained with the variables of wound contraction and mast cell number were submitted to Analysis of Variance (ANOVA) in a split-plot design in time, and the means were compared by Student's t-test with $5 \%$ significance $(p<0.05)$. The analyses were made using the Prism 4 software (GraphPad, La Jolla, CA, USA).

\section{Results}

Evaluation of the wound contraction using the $5 \%$ oil ointment, it was observed that, immediately after the surgery, the wound area increased, which interfered with the contraction evaluation on the $4^{\text {th }}$ day. From the $7^{\text {th }}$ postoperative day, the wounds were undergoing contraction process. Analysing the means of the percentage results, the GTreat wounds contracted more than the GCtrl wounds on the $14^{\text {th }}$ day $(\mathrm{p}<0.05)$. In $21^{\text {st }}$ days the wounds were already fully closed (Figure 1).

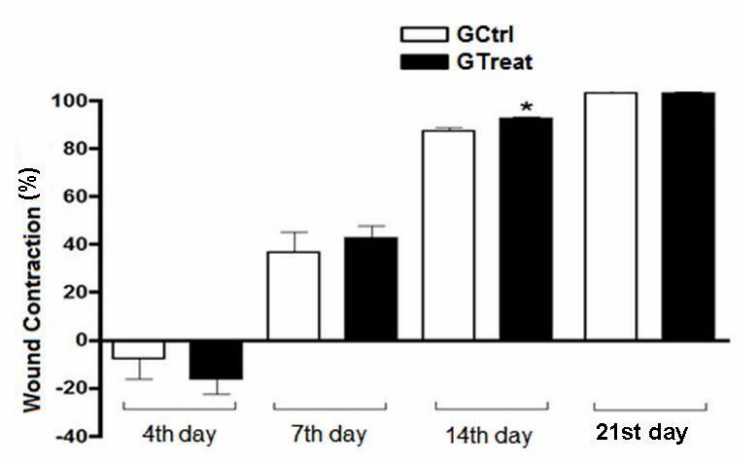

FIGURE 1 - Mean values and standard errors of wound contraction $\left(\mathrm{cm}^{2}\right)$ for both sides: control (GCtrl) and treated (GTreat) with Brazilian pepper oil ointment at $5 \%$ for 4 th, 7 th, 14 th and 21 st postoperative days. Student's t-test $\left({ }^{*} \mathrm{p}<0.05\right)$. 
The GCtrl presented some dispersed mast cells near the granulation tissue or around the newly formed capillaries (Figures $2 \mathrm{~A}$ and $2 \mathrm{C}$ ). The treated group, GTreat, showed multiple mast cell aggregates on the fibrovascular tissue (Figures 2B and 2D) and had a higher quantity on the $7^{\text {th }}$ postoperative day. In this period, a significant increase in mast cell number was observed in GTreat in comparison to GCtrl $(\mathrm{p}<0.001)$ (Figure 3). No significant differences were observed on the $4^{\text {th }}, 14^{\text {th }}$ and $21^{\text {st }}$ days.
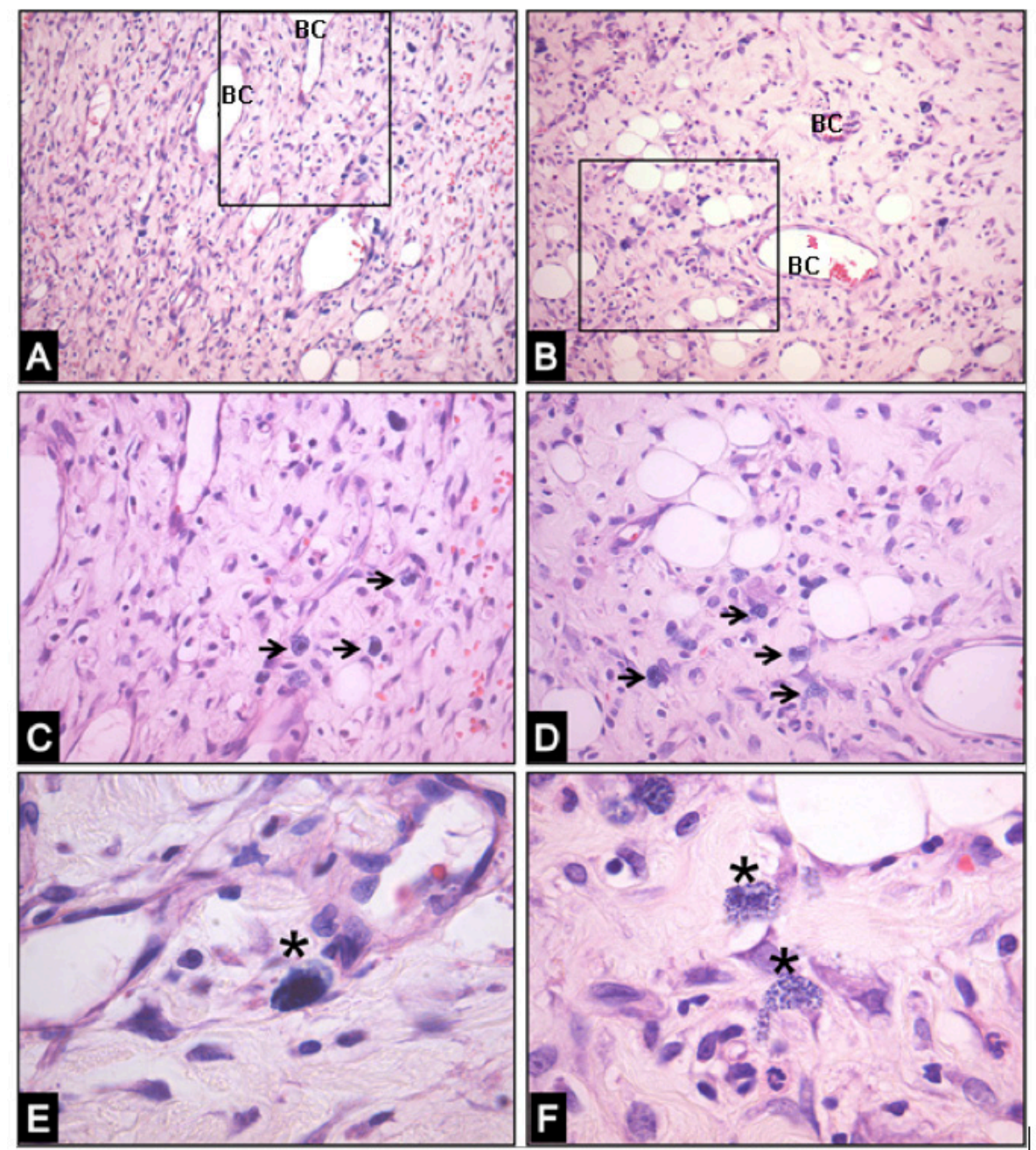

FIGURE 2 - Photomicrografs of the skin wounds sessions on the control side (A, C and E) and on the side treated with Brazilian pepper oil ointment at $5 \%$ for 7 days (B, D and F), male rats, H.E. A - Granulation tissue with newly formed blood capillaries (BC) and conjunctive tissue, x200. B Granulation tissue showing exuberant collagen fibers, newly formed capillaries and adipose cells (framework), x200. C - Some mast cells (arrows) dispersed in the granulation tissue, x200. D - Mast cells aggregates (arrows) distributed multifocally on the fibrovascular tissue, x400. F - Mast cell detail (asterisk) located around the blood capillary, x1000. F) Well-distinct mast cells (asterisks) containing cytoplasmic granules that mask the spherical core, $\mathrm{x} 1000$. 


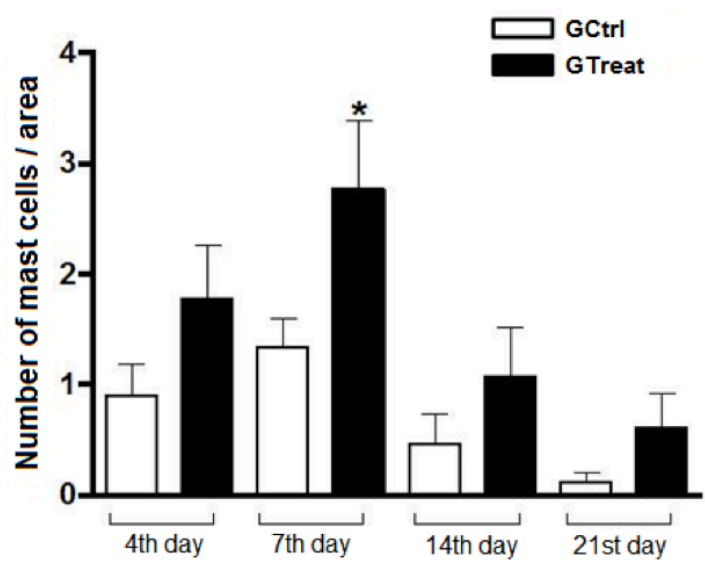

FIGURE 3 - Mean values and standard errors of the mast cells number for both sides: control (GCrtl) and treated (GTreat) with Brazilian pepper oil ointment at $5 \%$ for $4^{\text {th }}, 7^{\text {th }}, 14^{\text {th }}$ and $21^{\text {st }}$ postoperative days. Student's t-test $(\mathrm{p}<0.05)$.

\section{Discussion}

Non-local irritation, allergies or possible inflammations that could be caused by the vehicle used in the formulation were observed. Crusts were present in both groups on the $7^{\text {th }}$ and $14^{\text {th }}$ postoperative days. The granulation tissue was more uniform in GTreat.

Mast cells were observed both on the side that received the vaseline and lanolin-based ointment (GCtrl) and on the side that received the 5\% BPT leaf oil-based ointment (GTreat) on the $4^{\text {th }}, 7^{\text {th }}, 14^{\text {th }}$ and $21^{\text {st }}$ days after skin wound formation. The GCtrl presented some dispersed mast cells near the granulation tissue or around the newly formed capillaries (Figures 2A and 2C). The treated group showed multiple mast cell aggregates on the fibrovascular tissue (Figures 2B and 2D). Mast cells were observed in higher quantities on the $7^{\text {th }}$ postoperative day. In this period, a significant increase in mast cell number was observed in GTreat in comparison to GCtrl $(\mathrm{p}<0.001)$ (Figure 3). No significant differences were observed on the $4^{\text {th }}, 14^{\text {th }}$ and $21^{\text {st }}$ days.

On the $7^{\text {th }}$ postoperative day, the wounds in GTreat showed an increased number of mast cells, better vascular proliferation, higher concentration of fibroblasts and evident epithelial buds. A high concentration of polymorphonuclear cells was observed in both groups on the $4^{\text {th }}$ and $7^{\text {th }}$ postoperative days. The amount of these cells was progressively smaller on the $14^{\text {th }}$ and $21^{\text {st }}$ days. On the $14^{\text {th }}$ day, there was an intense proliferation of capillaries, and the collagen was better organised. Conversely, other studies have reported no increase in vascular proliferation and reepithelialisation of skin wounds in rats treated with HAE (hydroalcoholic extract) of Brazilian pepper ${ }^{16}$.

Essential oils are products of the secondary metabolism of plants and have complex chemical compositions, which frequently feature terpenes and phenylpropanoids ${ }^{19}$. These constituents are required for vegetal survival; for example, they play a key role in the defence against microorganisms ${ }^{9,11}$. It has been scientifically established that approximately $60 \%$ of essential oils have antifungal properties and $35 \%$ show antibacterial properties ${ }^{11}$. Barbosa et $a l .{ }^{21}$ studied the seasonal variation in the chemical compounds of Schinus terebinthifolius Raddi and concluded that there are variations between the sesquiterpenes and diterpenes collected from leaves over the year. They also observed that the metabolisms of these two classes are related, where the increase of one class follows the decrease of the other.

The essential oils from BPT leaves collected in different regions of the world have shown distinct chemotypes ${ }^{19}$. Most oil samples analysed in India revealed $\alpha$-pinene as the main component ${ }^{21} \cdot p$-Cymen and caryophyllene have been reported for their inhibitive effect on microorganisms ${ }^{22}$. Although a specific chemical compound can cause antimicrobial activity, this activity usually results from synergy between several chemical compounds present in the oil.

In this study, the chemical compounds present in BPT oil benefited the mast cell action owing to the significant increase in the number of these cells observed in the healing stage ( $7^{\text {th }}$ day) and the increase in the degree of epithelial contraction on the $14^{\text {th }}$ day of cicatrisation. Secondarily, the degranulation of mast cells and the liberation of its mediators in the initial phase of the inflammatory process, as well as the regulation of leukocyte infiltration inside the wound, seem to be influenced by the BPT oil compounds ${ }^{2,23}$. There are no data about how the BPT oil compounds play a role in mast cell activities in the proliferative phase of cicatrisation. However, several reports have evaluated the role of mast cells in cicatrisation. It is known that mast cells maintain their participation in collagen remodelling during the final phase of wound healing in mast cell-deficient mice ${ }^{6}$. In models involving immune cells and scar hypertrophy, the inhibition of inflammatory response, including the reduction of mast cells, is effective in limiting scar formation $^{23}$. In the present work, the number of mast cells in the final phase of healing in GTreat showed no significant difference compared with the GCtrl.

It should be taken into account the route of administration and the type of Schinus terebinthifolius Raddi preparation. Carlini et al. ${ }^{15}$ administering a cup of tea with Schinus terebinthifolius Raddi bark, obtained induced bone malformations in fetuses and 
a slight delay in recovery time of the postural reflex was observed in female pups from animals treated for 18 days. In the healing process, the topic use of the hydroalcoholic extract of aroeira removed the delayed the reepitelization of the skin wounds in rats when compared with the bark type ${ }^{16}$.

In our study, for the formulation of herbal ointment, an emollient (solid vaseline) and a demulcent (anhydrous lanolin) were used. Lanolin may contain some pro-oxidants that may affect the stability of certain drugs, and therefore, the addition of an antioxidant (Vit. E) to the lanovaseline ointment is indicated ${ }^{24}$. The healing action of essential oils from several plants has been tested. The essential oil of copaiba induces increased neovascularisation in the skin flaps of rats $^{20}$. Regarding in vitro use, Silva et al. ${ }^{19}$ observed favourable effects during the treatment of canine otitis with Schinus terebenthifolius Raddi essential oil.

The present research led to the development of a BPT essential oil-based ointment at a concentration sufficient to enhance the tissue recovery process and verified the action of this oil in mast cell concentration. Other studies, including those focusing on angiogenesis in the healing process and new concentrations in herbal medicine are being developed to improve the ideal concentration for use in skin wounds.

\section{Conclusion}

The ointment containing 5\% Brazilian pepper leaf oil increases mast cell concentration and favours contraction in skin wounds in rats.

\section{References}

1. Wulff BC, Wilgus TA. Mast cell activity in the healing wound: more than meets the eye? Exp Dermatol. 2013;22(8):507-10. doi: 10.1111/exd.12169.

2. Ng MFY. The role of mast cells in wound healing. Int Wound $\mathrm{J}$. 2010;7(1):55-61. doi: 10.1111/j.1742-481X.2009.00651.x.

3. Oehmichen M, Gronki T, Meissner C, Anlauf M, Schwark T. Mast cell reactivity at the margin of human skin wounds: an early cell marker of wound survival? Forensic Sci Int. 2009;191(1-3):1-5. doi: 10.1016/j.forsciint.2009.05.020.

4. Gourevitch D, Kossenkov AV, Zhang Y, Clark L, Chang C, Showe LC, Heber-Katz E. Inflammation and its correlates in regenerative wound healing: An alternate perspective. Adv Wound Care (New Rochelle). 2014:3(9):592-603. doi: 10.1089/wound.2014.0528.

5. Tonnesen MG, Feng X, Clark RA, Lark RA. Angiogenesis in wound healing. J Investig Dermatol Symp Proc. 2000;5(1):40-6. doi: 10.1046/j.1087-0024.2000.00014.x.

6. Iba Y, Shibata A, Kato M, Masukawa T. Possible involvement of mast cells in collagen remodelling in the late phase of cutaneous wound healing in mice. Int Immunopharmacol. 2004;4(14):187380. doi: 10.1016/j.intimp.2004.08.009.

7. Pazyar N, Yaghoobi R, Rafiee E, Mehrabian A, Feily A. Skin wound healing and phytomedicine: a review. Skin Pharmacol Physiol. 2014;27(6):303-10. doi: 10.1159/000357477.

8. Desmarchelier C. Neotropics and natural ingredients for pharmaceuticals: Why isn't south american biodiversity on the crest of the wave? Phytother Res. 2010;24(6):791-9. doi: 10.1002/ ptr.3114.

9. Gomes FS, Procópio TF, Napoleão TH, Coelho LC, Paiva PM. Antimicrobial lectin from Schinus terebinthifolius leaf. J Appl Microbiol. 2013;114(3):672-9. doi: 10.1111/jam.12086.

10. Melo MC, Gadelha DN, Oliveira TK, Brandt CT. Alcohol extract of Schinus terebinthifolius Raddi (anacardiaceae) as a local antimicrobial agent in severe autogenously fecal peritonitis in rats. Acta Cir Bras. 2014;29(Suppl.1):52-6. http://dx.doi.org/10.1590/ S0102-86502014001300010.

11. Barbieri DS, Tonial F, Lopez PV, Sales Maia BH, Santos GD, Ribas MO, Glienke C, Vicente VA. Antiadherent activity of Schinus terebinthifolius and Croton urucurana extracts on in vitro biofilm formation of Candida albicans and Streptococcus mutans. Arch Oral Biol. 2014;59(9):887-96. doi: 10.1016/j.archoralbio.2014.05.006.

12. Morais TR, da Costa-Silva TA, Tempone AG, Borborema SE, Scotti MT, de Sousa RM, Araujo AC, de Oliveira A, de Morais SA, Sartorelli P, Lago JH. Antiparasitic activity of natural and semisynthetic tirucallane triterpenoids from Schinus terebinthifolius (Anacardiaceae): structure/activity relationships. Molecules. 2014; 19(5):5761-76. doi: 10.3390/molecules19055761.

13. Lucena PL, Ribas Filho JM, Mazza M, Czeczko NG, Dietz UA, Correa Neto MA, Henriques GS, Santos OJ, Ceschin AP, Thiele ES. Evaluation of the aroreira (Schinus terebinthifolius Raddi) in the healing process of surgical incision in the bladder of rats. Acta Cir Bras. 2006;21(Suppl.2):46-51. http://dx.doi.org/10.1590/S010286502006000800008 .

14. Vieira DR, Amaral FM, Maciel MC, Nascimento FR, Libério SA, Rodrigues VP. Plant species used in dental diseases: Ethnopharmacology aspects and antimicrobial activity evaluation. J Ethnopharmacol. 2014;155(3):1441-9. doi: 10.1016/j. jep.2014.07.021.

15. Carlini EA, Duarte-Almeida JM, Tabach R. Assessment of the toxicity of the Brazilian pepper trees Schinus terebinthifolius Raddi (Aroeira-da-praia) and Myracrodruon urundeuva Allemão (Aroeirado-sertão). Phytother Res. 2013;27(5):692-8. doi: 10.1002/ptr.4767.

16. Branco Neto ML, Ribas Filho JM, Malafaia O, Oliveira Filho MA, Czeczko NG, Aoki S, Cunha R, Fonseca VR, Teixeira HM, Aguiar LR. Evaluation of hydroalcoholic extract of Aroeira (Schinus terebinthifolius Raddi) in the healing process of wound skin in rats. Acta Cir Bras. 2006;21(Suppl.2):17-21. http://dx.doi.org/10.1590/ S0102-86502006000800004.

17. Estevão LR, Mendonça Fde S, Baratella-Evêncio L, Simões RS, Barros ME, Arantes RM, Rachid MA, Evêncio-Neto J. Effects of aroeira (Schinus terebinthifolius Raddi) oil on cutaneous wound healing in rats. Acta Cir Bras. 2013;28(3):202-9. http://dx.doi. org/10.1590/S0102-86502013000300008.

18. Lipinski LC1, Wouk AF, da Silva NL, Perotto D, Ollhoff RD. Effects of 3 topical plant extracts on wound healing in beef cattle. Afr J Tradit Complement Altern Med. 2012;9(4):542-7. http://dx.doi. org/10.4314/ajtcam.v9i4.11.

19. Silva AB, Silva T, Franco ES, Rabelo SA, Lima ER, Mota RA, Câmara CAG, Pontes Filho NT, Lima Filho JV. Antibacterial activity, chemical composition, and cytotoxicity of leaf's essential oil from Brazilian pepper tree (Schinus terebinthifolius, Raddi). Braz J Microbiol. 2010;41(1):158-63. doi: 10.1590/S1517838220100001000023.

20. Estevão LR, Medeiros JP, Baratella-Evêncio L, Simões RS, Mendonça Fde S, Evêncio-Neto J. Effects of the topical 
administration of copaiba oil ointment (Copaifera langsdorffii) in skin flaps viability of rats. Acta Cir Bras. 2013;28(12):863-9. http:// dx.doi.org/10.1590/S0102-86502013001200009.

21. Barbosa LCA, Demuner AJ, Clemente AD, Paula VF, Ismail FMD. Seasonal variation in the composition of volatile oils from Schinus terebinthifolius Raddi. Quím Nova. 2007;30(8):1959-65. http:// dx.doi.org/10.1590/S0100-40422007000800030.

22. Cox SD, Mann CM, Markham JL. Interactions between components of the essential oil of Melaleuca alternifolia. J Appl Microbiol. 2001;91(3):492-7. doi: 10.1046/j.1365-2672.2001.01406.x.

23. Wilgus TA. Immune cells in the healing skin wound: Influential players at each stage of repair. Pharmacol Res. 2008;58(2):112-6. doi: 10.1016/j.phrs.2008.07.009.

24. Gulcan E, Kuçuk A, Çayci K, Tosun M, Emre H, Koral L, Aktan Y, Avsar U. Topical effects of nebivolol on wounds in diabetic rats. Eur J Pharm Sci. 2012;47(2):451-5. doi: 10.1016/j.ejps.2012.06.017.

\section{Correspondence:}

Joaquim Evêncio-Neto

Universidade Federal Rural de Pernambuco/DMFA

Rua Manoel de Medeiros, $\mathrm{s} / \mathrm{n}$

52171-900 Recife - PE Brasil

Tel.: (5581)3320-6390

Fax: (5581)3265-5948

evencioneto@bol.com.br

evencioneto@pq.cnpq.br

Received: Dec 19, 2014

Review: Feb 20, 2015

Accepted: Mar 18, 2015

Conflict of interest: none

Financial sources: Pernambuco Research Foundation (FACEPE), Minas

Gerais Research Foundation (FAPEMIG) and National Council for

Scientific and Technological Development (CNPq)

${ }^{1}$ Research performed at Animal Department of Pharmacy, Federal Rural University of Pernambuco (UFRPE), Brazil. Part of PhD degree thesis, Postgraduate Program in Animal Bioscience. Tutor: Joaquim EvêncioNeto. 